\title{
Struktur Histopatologis Lambung Tikus Wistar yang Diberi Ekstrak Daun Singkong (Manihot utillisima Pohl.) secara Kronik
}

\author{
Nugrahaningsih WH ${ }^{\bowtie 1)}$, Addina Nur Luthfiani ${ }^{1)}$, Lisdiana $^{1)}$, Endah Peniati ${ }^{1)}$ \\ 1) Jurusan Biologi, Fakultas Matematika dan Ilmu Pengetahuan Alam Universitas Negeri Semarang, \\ Indonesia
}

\begin{tabular}{l}
\hline Info Artikel \\
\hline Diterima: 1 September \\
2021 \\
Disetujui: 30 September \\
2021 \\
Dipublikasikan: 30 \\
November 2021 \\
\hline Keywords: \\
Cassava leaves, gastric \\
histopathological structure, \\
chronic toxicity \\
Daun singkong, struktur \\
histopatologi lambung, \\
toksisitas kronik \\
\hline
\end{tabular}

\begin{abstract}
Cassava leaves contain sodium $(\mathrm{Na})$, potassium $(\mathrm{K})$, and iron $(\mathrm{Fe})$ which can increase the body's blood pressure. In addition, the chemical content of cassava leaves can also act as an anti-hypertension agent. However, cassava leaves also contain hydrogen cyanide $(H C N)$ which at certain doses can cause toxic effects. This study aims to determine the safety of long-term consumption by observing the damage to gastric organ cells in Wistar rats after administration of cassava leaf extract (Manihot uttilisima Pohl.) for 90 days. Cassava leaf extract was made by maceration method using distilled water as a solvent. This research is an experimental laboratory research with a posttest only control group research design. This study used 36 Wistar rats which were randomly divided into 4 groups consisting of group I (control) given $10 \mathrm{ml} / \mathrm{w}$ of distilled water, group II (treatment group) given cassava leaf extract $80 \mathrm{mg} / \mathrm{bb}$, group III (treatment group) given cassava leaf extract $400 \mathrm{mg} / \mathrm{bb}$, group IV (treatment group) was given cassava leaf extract $2000 \mathrm{mg} / \mathrm{bb}$. Organ sampling was carried out after 90 days of treatment, all rats were killed by cervical dislocation, then their stomach organs were taken. To determine the histopathological structure between the control group and the treatment group, the data from the gastric histopathological test of Wistar rats were analyzed using descriptive analysis. did not affect the histopathological structure of the stomach of Wistar rats.
\end{abstract}

(C) 2021 Universitas Negeri Semarang

$\square$ Alamat korespondensi:

Gedung D6 Lt. 1 J1 Raya Sekaran Gunugpati, Semarang

E-mail: nugrahaningsihwh@mail.unnes.ac.id 


\section{PENDAHULUAN}

Indonesia memiliki sekitar 30.000 jenis tumbuhan dan 7.000 diantaranya memiliki khasiat sebagai tanaman obat. Sebanyak 2500 jenis diantaranya merupakan tanaman obat. Salah satu tanaman yang digunakan sebagai obat tradisonal yaitu daun singkong (Manihot utilissima Pohl.). Daun singkong banyak dimanfaatkan sebagai obat kanker, konjungtivitis, disentri, abses, diare, marasmus, flu, peradangan, reamtik sakit kepala, prostatitis dan lain-lain (Miladiyah et al., 2011). Daun singkong memiliki kandungan falavonid yang dapat berfungsi sebagai antioksidan. Aktivitas antioksidan meningkat secara signifikan setelah proses digesti pada saluran gastrointestinal. Bioaksesibilitas fenolik bersifat stabil dan menunjukkan aktivitas ttinggi. Daun singkong dapat dianggap sebagai sumber polifenol alami yang andal dan senyawa antioksidan yang memiliki bioaksesibel yang baik (Laya \& Koubala, 2020). Daun singkong mengandung natrium $(\mathrm{Na})$, kalium $(\mathrm{K})$, dan besi $(\mathrm{Fe})$ yang mampu meningkatkan tekanan darah (Nugrahaningsih, et al. 2017). Oleh karena itu daun singkong dapat dijadikan sebagai bahan baku obat, sehingga fitofarmaka menjadi suatu pilihan menarik dan dapat dikembangkan untuk mengatasi permasalahan hipotensi ortotestik. Fitofarmaka dapat didefinisikan sebagai obat dari bahan alam terutama dari alam nabati (Dewoto,2007).

Umbi dan daun singkong merupakan bagian dari Cassava yang banyak mengandung linamarin. Linamarin dan lotaustralin merupakan senyawa glikosida dari hidrogen sianida (HCN) yang pada dosis tertentu dapat menyebabkan efek toksik. Hidrogen sianida jika dikonsumsi dalam jumlah banyak akan menyebabkan keracunan (Nurdiana, 2013). Toksisitas ini diakibatkan karena kemampuan dalam menghambat aktivitas metalloenzim, terutama cytochrome c oxidase yang merupakan enzim akhir dari respirasi transport elektron. Glikosida sianogenik dalam daun singkong digolongkan dalam sianogen linamarin (Gleadow \& Moller, 2014). Daun singkong mentah masih memiliki kandungan sianida yang tinggi sehingga bila dikonsumsi dalam jangka panjang dapat menimbulkan perubahan pada indikator biokimia fungsi hati dan hematologi (Abuh, et al::2016). Penelitian dengan pemberian sianida yang diekstrak dari daun singkong menyebabkan terjadinya perubahan histopatologi pada sel hati seiring meningkatnya dosis ekstrak yang diberikanToksisitas yang disebabkan oleh sianida bebas (CN-) telah dilaporkan, namun toksisitas yang disebabkan oleh glikosida belum dilaporkan. Oleh karena itu, perlu diteliti bagaimana keamanan daun singkong yang dikonsumsi dalam jangka panjang terhadap tubuh, terutama terhadap kesehatan organ salah satunya lambung.

Pengembangan bahan alam menjadi fitofarmaka maupun obat herbal berstandar memerlukan data dari aspek keamanan dan efektifitas bahan herbal. Data keamanan dilakukan dengan serangkaian uji preklinik dan uji klinik. Salah satu uji keamanan dapat dilakukan berupa uji toksisitas. Uji toksisitas akut dengan uji Brine Shrimp Lethality Test menunjukkan nilai LC50 yang cukup tinggi $(493,86 \mu \mathrm{g} / \mathrm{ml})$ sehingga diperkirakan aman untuk dikonsumsi (Putri, et.al, 2021). Penelitian ini bertujuan untuk menganalisis keamanan konsumsi jangka panjang ekstrak daun singkong dengan melihat pengaruhnya terhadap mukosa organ lambung pada tikus Wistar. 


\section{METODE PENELITIAN}

\section{Pembuatan Ekstrak Daun Singkong}

Daun singkong yang digunakan adalah daun ke-5 sampai daun ke-10. Daun singkong kemudian dicuci menggunakan air mengalir dan dikeringkan di dalam oven pada suhu $50^{\circ}$ selama $24 \mathrm{jam}$. Daun yang sudah kering selanjutnya dihaluskan menggunakan blender hingga didapat serbuk kering. Metode ekstraksi yang digunakan dalam penelitian ini adalah metode maserasi. Serbuk kering diekstraksi menggunakan pelarut akuades dengan perbandingan 1:5 dan diinkubasi dalam lemari pendingin selama 5 hari. Setelah 5 hari, supernatan diambil menggunakan pipet kemudian diuapkan menggunakan rotary evaporator. Ekstrak yang diperoleh dalam bentuk serbuk halus.

\section{Perlakuan Hewan Coba}

Penelitian menggunakan 36 tikus putih Wistar yang terdiri dari 24 tikus jantan dan 12 tikus betina yang telah diaklimatisasi selama 7 hari kemudian dikelompokan menjadi 4 kelompok masing-masing kelompok 9 ekor.Hewan percobaan ditempatkan pada kandang individual yang dibersihkan setiap 4 hari sekali.Tikus diberi pakan standar dan air minum secara teratur selama penelitian. Proses pemberian ekstrak daun singkong dilakukan setiap pagi dengan menggunakan sonde lambung selama 90 hari.Kelompok kontrol $(\mathrm{K})$ adalah kelompok yang tidak diberi ekstrak daun singkong. Kelompok perlakuan P1,P2,P3 diberi kan ekstrak daun singkong secara oral masing-masing dengan dosis 80, 400, dan $2000 \mathrm{mg} / \mathrm{kg}$. Ekstrak diberikan dalam bentuk larutan dengan pelarut akuades.

\section{Preparasi Sampel Histopatologi}

Pengambilan sampel organ dilakukan pada hari ke-90 perlakuan. Tikus dimatikan dengan cara dislokasi cervical kemudian diambil organ lambung dan dicuci dalam tempat yang sudah terisi air. Setelah itu, organ dimasukan ke dalam wadah yang berisi formalin $10 \%$. Kemudian sampel organ lambung direndam dalam larutan alkohol bertingkat (dehidrasi) dimulai dari konsentrasi 70\%, 80\%, 90\%, 95\%, dan $100 \%$. Selanjutnya, dijernihkan dalam xylol (clearing), sebelum akhirnya ditanam dalam paraffin (embedding).

Jaringan dalam blok paraffin diiris dengan ketebalan 5-6 $\mu \mathrm{m}$ menggunakan mikrotom (Indoexim,India),kemudian diletakkan pada gelas objek, dan disimpan dalam inkubator pada suhu $40{ }^{\circ} \mathrm{C}$ selama 24 jam. Hasil sayatan diwarnai dengan pewarnaan baku hematoksin eosin (HE). Pewarnaan HE digunakan untuk melihat struktur jaringan yang diduga mengalami perubahan patologis. Proses pewarnaan diawali dengan deparafinasi jaringan dengan xylol dan rehidrasi dengan alkohol bertingkat, kemudian diletakan kembali di dalam xylol selama 24 jam untuk penjernihan. Selanjutnya jaringan diambil dan diberi entelan sebelum ditutup dengan cover glass (mounting). Preparat diamati dibawah mikroskop dengan perbesaran bertingkat mulai dari $10 \mathrm{x}$ sampai mendapatkan visualisasi yang jelas. 


\section{Penilaian struktur histopatologis}

Penilaian struktur histopatologis lambung dilakukan dengan melihat tiga indikator kerusakan sel yaitu nekrosis, degenerasi sel, dan infiltrasi sel radang. Pengamatan dilakukan pada lima lapangan pandang dengan perbesaran 400X. Penilaian secara kualitatif dilakukan dengan memberikan skor untuk kelima lapang pandang tersebut. Skor 0 menunjukkan tidak ada nekrosis, degenerasi sel, dan infiltrasi sel radang pada seluruh pengamatan. Skor 1 bila didapatkan nekrosis, degenerasi sel, dan infiltrasi sel radang pada satu fokus pengamatan (perubahan fokal). Skor 2 bila didapatkan nekrosis, degenerasi sel, dan infiltrasi sel radang pada beberapa fokus pengamatan (perubahan multifokal). Skor 3 bila didapatkan nekrosis, degenerasi sel, dan infiltrasi sel radang secara menyeluruh (difusa). Penilaian struktur histopatologis dilakukan oleh ahli patologi anatomi.

\section{HASIL DAN PEMBAHASAN}

Penelitian ini memberikan data kualitatif berupa tanda-tanda toksik klinis pada hewan coba, dan data skoring histopatologis mukosa lambung. Baik data tanda toksik klinik maupun data skoring perubahan struktur histopatologi lambung tikus Wistar dianalisis secara deskriptif.

\section{Uji Toksisitas Kronik}

Uji toksisitas kronik dari efek ekstrak daun singkong dilakukan selama 90 hari perlakuan. Pengamatan terhadap tanda toksik klinik dilakukan setiap hari dan dicatat perubahan-perubahan yang terjadi. Hasil pengamatan tanda toksik klinik tikus Wistar disajikan pada Tabel 1.

Tabel 1. Tanda toksik klinik tikus wistar selama 90 hari pemberian ekstrak daun singkong

\begin{tabular}{|c|c|c|c|c|c|c|c|c|c|c|c|c|}
\hline \multirow{3}{*}{ Sistem Organ } & \multicolumn{12}{|c|}{ Jumlah Kasus } \\
\hline & \multicolumn{4}{|c|}{ Bulan ke-1 } & \multicolumn{4}{|c|}{ Bulan ke-2 } & \multicolumn{4}{|c|}{ Bulan ke-3 } \\
\hline & $\mathbf{K}$ & P1 & P2 & P3 & $\mathbf{K}$ & P1 & P2 & P3 & $\mathbf{K}$ & P1 & P2 & P3 \\
\hline Mortalitas & - & - & - & $1^{1}$ & & - & - & $\begin{array}{c}1^{2} \\
7^{3}\end{array}$ & - & - & - & $\mathrm{X}$ \\
\hline $\begin{array}{l}\text { Sistem saraf } \\
\text { pusat dan } \\
\text { somatomotor }\end{array}$ & - & - & - & $9^{4}$ & - & - & - & $\mathrm{X}$ & - & - & - & $\mathrm{X}$ \\
\hline Pencernaan & - & - & - & - & - & - & - & $\mathrm{X}$ & - & - & - & $\mathrm{X}$ \\
\hline Mata & - & - & - & - & - & - & - & $\mathrm{X}$ & - & - & - & $\mathrm{X}$ \\
\hline Mulut & - & - & $7^{5}$ & $9^{5}$ & - & - & - & $\mathrm{X}$ & - & - & - & $\mathrm{X}$ \\
\hline Hidung & - & - & $7^{6}$ & $9^{6}$ & - & - & - & $\mathrm{X}$ & - & - & - & $\mathrm{x}$ \\
\hline $\begin{array}{l}\text { Jeterangan } \\
\text { Seekor tikus dit } \\
\text { terlihat lemas da } \\
\text { Seekor tikus ker } \\
\text { yang sama deng } \\
\text { Semua tikus wi } \\
\text { pendarahan par } \\
\text { nafsu makan hil } \\
\text { Tikus wistar terl } \\
\text { Tikus wistar me }\end{array}$ & thg. & us se & $\begin{array}{l}\text { belun } \\
\text { ok P3 }\end{array}$ & $\begin{array}{l}\text { kan } \\
\text { mati } \\
\text { anya } \\
\text { pac }\end{array}$ & ha & $\begin{array}{l}\text { ke-4 } \\
\text { its se } \\
\text { aga. }\end{array}$ & $\mathrm{di}$ & min & $\begin{array}{l}\text { asi } b \\
\text { fisit }\end{array}$ & cena & $\begin{array}{l}\text { men } \\
\text { lem }\end{array}$ & $\begin{array}{l}\text { ndisi } \\
\text { Lami } \\
\text { dan }\end{array}$ \\
\hline
\end{tabular}


Struktur Histopatologi Lambung Penilaian perubahan histopatologi organ lambung dari tikus Wistar pada setiap kelompok percobaan menggunakan mikroskop. Skoring preparat histopatologi lambung masing-masing dilakukan lima lapang pandang mikroskop dengan perbesaran 400x dan diambil skor integritas mukosa tertinggi dari ke-5 lapang pandang tersebut, hasilnya dapat dilihat pada Tabel 2.

Tabel 2. Skoring histopatologis mukosa lambung setelah pemberian ekstrak daun singkong selama 90 hari

\begin{tabular}{cccccc}
\hline Kelompok & \multicolumn{5}{c}{ Lapang Pandang } \\
\hline & I & II & III & IV & V \\
\hline K & 0 & 0 & 0 & 0 & 0 \\
P1 & 0 & 0 & 0 & 0 & 0 \\
P2 & 0 & 0 & 0 & 0 & 0 \\
P3 & 0 & 0 & 0 & 0 & 0 \\
& & & & & \\
& & & & & \\
\end{tabular}

Hasil penilaian perubahan histopatologi lambung pada Tabel 2 mengindikasikan bahwa semua tikus Wistar pada semua preparat menunjukkan skor 0 yang artinya tidak ada perubahan pada struktur sel lambung.

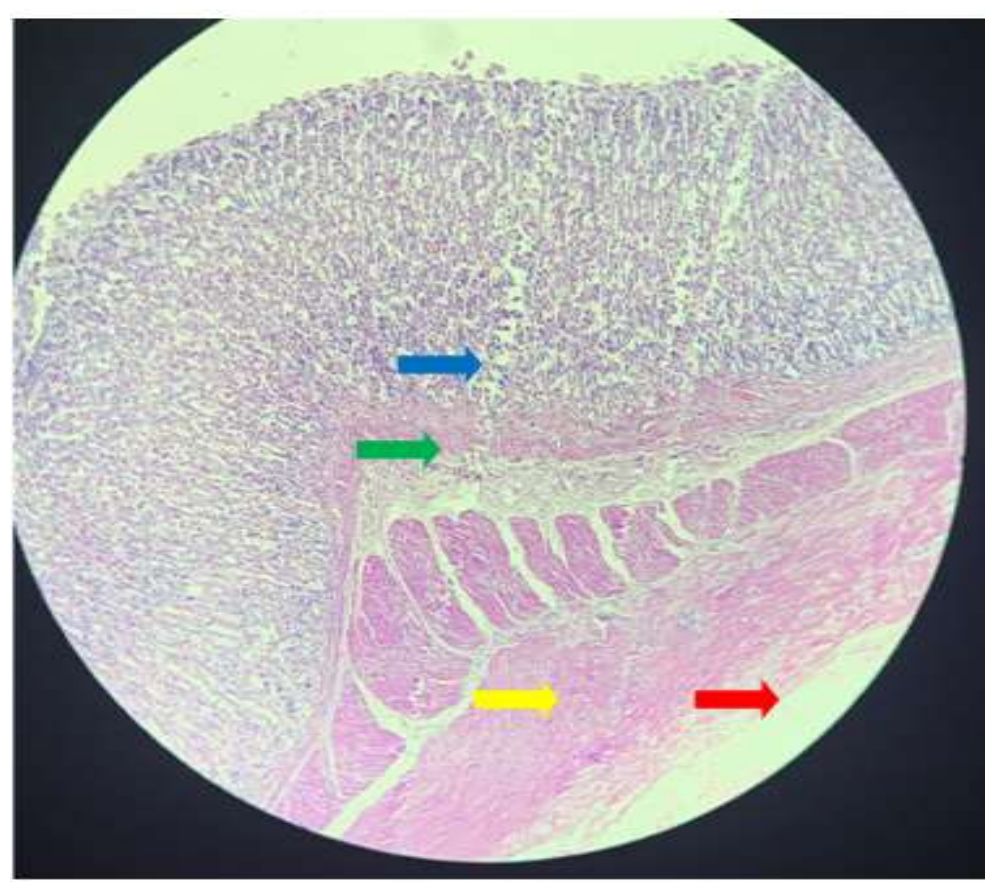

Gambar 1. Struktur histolopatologis mukosa lambung tikus wistar yang diberi ekstrak daun singkong dosis 2000 mg selama 90 hari. Tidak didapatkan gambaran sel nekrosis, degeneratif maupun infiltrsi sel radang pada lapisan mukosa (panah biru), submukosa (panah hijau), muskularis eksterna (panah kuning), serosa (panah merah). (Pembesaran 40X10) 
Hasil penelitian menunjukkan bahwa ekstrak daun singkong dapat menyebabkan efek toksik apabila diberikan pada dosis yang tinggi (2000 mg/ kg yaitu pada perlakuan kelompok P3. Dosis ekstrak daun singkong $0,80,400$, dan $2000 \mathrm{mg} / \mathrm{kg}$ yang diberikan pada tikus $200 \mathrm{~g}$ jika dikonversikan berdasarkan perhitungan Brunton et al. (2008) ke dosis manusia $70 \mathrm{~kg}$ maka diperoleh dosis ekstrak daun singkong untuk manusia adalah $0 ; 4,48 ; 22,4$; dan 112 g. Dari hasil pengamatan pada mulai timbulnya gejala toksik klinik, dapat diketahui bahwa ambang batas aman konsumsi daun singkong pada manusia kurang dari 22,4 g ekstrak setiap harinya. Batas aman konsumsi daun singkong ini cukup tinggi mengingat setiap $1 \mathrm{~kg}$ daun singkong kering menghasilkan ekstrak daun singkong sebanyak 22,226 g.

Berbeda dengan hasil observasi tanda toksik klinik, hasil pengamatan struktur histopatologi lambung semua tikus Wistar pada semua kelompok tidak menunjukkan adanya perubahan baik nekrosis, degeneratif maupun infiltrasi sel radang. Ekstrak daun singkong tidak menimbulkan kerusakan atau perubahan histopatologis pada mukosa lambung kareana mengandung flavonoid yang dapat menekan proses inflamasi dengan menghambat produksi siklooksigenase (COX), baik COX-1 maupun COX-2 (Ribeiro, et al., 2015). COX-1 merupakan enzim yang secara fisiologi terdapat pada jaringan normal dan berperan dalam sekresi mucus untuk melindungi saluran pencernaan, dan pada proses penyembuhan luka. Ekspresi COX-2 akan meningkat bila terjadi stimulasi yang menyebabkan terjadinya inflamasi. Flavonoid tertentu memiliki afinitas yang tinggi dalam penghambatan kosubstrat COX dengan menempati peroxidase active sites dan mendonasikan elektron pada B-ring hydroxyl groups ke hematin (Bai, et al., 2021). Meilawaty (2013) menyatakan bahwa ekstrak daun singkong tidak menghambat ekspresi COX-2. Enzim siklooksiginase (COX) merupakan enzim pengkatalis prostaglandin. COX-1 dan COX-2. Enzim ini akan mengkatalisis biosintesis prostaglandin yang dapat meningkatkan resistensi dan memperkuat mukosa lambung (Peskar, 2001).

Ekstrak daun singkong juga memiliki efek protektif, yaitu sebagai antidot pada tikus yang diinduksi dengan kadmium (Adrian, et al., 2016). Kadar kadmium dalam hati dan ginjal mengalami penurunan signifikan setelah pemberian ekstrak daun singkong. Penurunan ini diakibatkan penyebaran kadmium ke organ lain atau terbentuknya kompleks dengan gugus fungsional dari ekstrak daun singkong. Pemberian ekstrak daun singkong juga dapat menurunkan kadar MDA, urea, kretainin, beberapa enzim hati seperti SGPT dan SGOT. Penelitian ini juga menunjukkan efek proteksi dari daun singkong terhadap nefrotoksisitas secara histopatologi pada tikus yang diinduksi dengan kadmium.

Hasil penelitian ini berbeda dengan penelitian yang dilakukan oleh Sheillavi et al. (2018) yang melakukan penelitian menggunakan ekstrak daun singkong untuk mengamati adanya efek toksik dan perubahan pada histopatologi hati. Penelitian ini menunjukkan bahwa tidak didapatkan adanya tandatanda klinis toksisitas (kejang, posisi lateral, tremor, sesak nafas, dan vokalisasi) dan kematian pada 
hewan coba. Namun, ditemukan adanya perubahan morfologis hepar tikus Wistar yang terpapar ekstrak daun singkong tersebut. Perubahan tersebut meliputi degenerasi parenkimatosa, degenerasi hidropik, dan nekrosis sel hepar. Perbedaan tersebut mungkin disebabkan oleh beberapa hal yaitu pada penelitian Sheillavi et al. (2018) ekstrak yang digunakan hanya ekstrak etanol dengan dosis $2000 \mathrm{mg} / \mathrm{kgBB}$. Setelah absorbs, alkohol mengalami proses metabolisme oleh sel hati. Oksidasi ethanol akan menghasilkan asetaldehid yang bersifat reaktif dan sangat toksik terhadap jaringan. Asetaldehid juga membentuk agregat dan hepatosit yang menurunkan sekresi protein dan memicu hepatomegali. Hal ini berkontribusi terhadap perubahan histospatologi hati (Sandoval et al., 2017). Selain itu kandungan sianida yang berbeda dapat terjadi karena adanya proses pengolahan. Beberapa proses pengolahan dapat menurunkan kadar sianida (Ginting \&Widodo, 2013). Secara umum, hasil penelitian ini dan penelitian Sheillavi et al. (2018) menunjukkan bahwa ekstrak daun singkong dengan dosis tinggi dapat memberikan efek toksik dengan atau tanpa perubahan histopatologi organ pada tikus Wistar.

\section{SIMPULAN}

Berdasarkan hasil penelitian dapat disimpulkan bahwa pemberian ekstrak daun singkong berbagai dosis selama 90 hari tidak memberikan pengaruh pada gambaran struktur histopatologi lambung tikus wistar. Tanda toksik klinik hanya muncul pada dosis pemberian yang sangat tinggi. Masih diperlukan penelitian untuk memastikan keamanan penggunaan ekstrak daun singkong dalam jangka panjang.

\section{DAFTAR PUSTAKA}

Abuh,A.,Bello, M.I, dan Thagriki, D. 2016. Biochemical and Hematological Evaluation of Cyanide Rich Extracts from Manihot utilissima on Wistar Rats. International Journal of Agriculture Innovations and Research. 4(4): 682-686

Adrian, Fachrial, E., Almahdy, Syaifullah, dan Zein, R. 2016. The Effect of ion (II) in the Kidney of Experimental Rats and Utilization of Cassava Leaves (Manihot utilissima) as Antidote. Research Journal of Pharmaceutical, Biological and Chemical Sciences.7(5):1228-123

Bai H, Yang C, Wang P, Rao S, Zhu BT. 2021. Inhibition of cyclooxygenase by blocking the reducing cosubstrate at the peroxidase site: Discovery of galangin as a novel cyclooxygenase inhibitor. European Journal of Pharmacology 899

Brunton, L.L., Parker, K.L., Blumenthal, D.K., \& Buxton, L.O. 2008. Goodman \& Gillman's Manual of Pharmacological Basis of Therapeutics. New York, USA: McGraw-Hill Medical, -Goodman \& Gilman's.

Dewoto, H.R. 2007. Pengembangan Obat Tradisional Indonesia Menjadi Fitofarmaka.Majalah Kedokteran Indonesia, 57 (7):205-211

Ginting E \& Widodo Y. 2013. Cyanide reduction in cassava root products through processing and selection of cultivars in relation to food safety. Bulletin Palawija 25: 25-36

Gleadow \& Moller, 2014. Cyanogenic glicosides: synthesis, physiologis and phenotypic plasticity. The annual Review of Plant Biologi, vol. 65:155-185

Laya a \& Koubala BB. 2020. Polyphenols in cassava leaves (Manihot esculenta Crantz) and their stability in antioxidant potential after in vitro gastrointestinal digestion. Heliyon 6

Meilawaty, Z. 2013. Efek Ekstrak Daun Singkong (Manihot utilissima) Terhadap ekspresi COX-2 pada Monosit yang dipapar LPS E.coli. Dental Jourmal. 46(4):196-201 
Maladiyah, I., Dayi, F. Desrini, S. 2011. Analgesic activity of ethanolic extract of manihot esculenta leaves in mice. Univ. med.30: 3-10

Nugrahaningsih WH, Lisdiana, \& Purwantoyo E. 2017. Mineral and Electrolyte Analysis of Manihot utilissima and Carica papaya Leaves: a Prospect of Anti Hypotension Agent. Proceedings Herbal and Traditional Medicine. Bangkok, Thailand: 121-126.

Nurdiana, A.R. 2013. Uji Ekstrak Daun Singkong (Manihot esculenta) terhadap Jumlah Neutrofill pada Proses Penyembuhan Luka Tikus (Rattus norvegicus). Jember: Fakultas Kedokteran Gigi Universitas Negeri Jember

Peskar,B.M, 2001. Role of cyclooxygenase isoforms in gastric mucosal defence. Journal of Physiology. 95:39

Putri RB, Nugrahaningsih WH, Dewi NK. 2021. Uji Toksisitas Ekstrak Daun Cassava Terhadap Larva Artemia salina Leach dengan Metode Brine Shrimp Lethality Test. Indonesian Journal of Mathematics and Natural Sciences 4 (2): 86-91

Ribeiro, D., Freitas, M., Tomé, S. M., Silva, A. M., Laufer, S., Lima, J. L., \& Fernandes, E. 2015. Flavonoids inhibit COX-1 and COX-2 enzymes and cytokine/chemokine production in human whole blood. Inflammation, 38(2), 858-870. https://doi.org/10.1007/s10753-014-9995-x

Sandoval, C, Belgica, V, Carlos, M.L, dan Mariano, D. 2017. Ethanol Intake and Toxicity: In Search of New Treatments. International Journal Morphol. 35(3):942-949

Sheillavi, F.A.Z, Normasari, R dan Cholis A. 2018. Toksisitas Akut Ekstrak Etanol Daun Singkong (Manihot esculenta) terhadap Histopatologi Hepar Tikus Putih Galur Wistar. Journal of Agromedicineand Medical Science. 4(1):45-49. 